GEOFIZIKA VOL. $38 \quad 2021$

DOI: https://doi.org/10.15233/gfz.2021.38.1

Original scientific paper

\title{
The assessment of local site effects and dynamic behaviour in Nicosia, Cyprus
}

\author{
Hilmi Dindar ${ }^{1,3}$, Mustafa Akgün ${ }^{1,2}$, Cavit Atalar ${ }^{3,4}$ \\ and $\ddot{O} z k a n$ Cevdet $\ddot{O} z d a \breve{g}^{1,5}$
}

\author{
${ }^{1}$ Institute of Natural and Applied Sciences, Dokuz Eylül University, Buca - İzmir, Turkey \\ ${ }^{2}$ Department of Geophysical Engineering, Engineering Faculty, Dokuz Eylül University, \\ Buca - İzmir, Turkey \\ ${ }^{3}$ Earthquake and Soil Research and Evaluation Centre, Near East University, Nicosia, Cyprus \\ ${ }^{4}$ Department of Civil Engineering, Near East University, Nicosia, Cyprus \\ ${ }^{5}$ Aegean Implementation and Research Centre, Dokuz Eylül University, Balçova - İzmir, Turkey
}

Received 3 February 2021, in final form 9 November 2020

Single-station microtremor measurements were conducted to investigate earthquake and soil behaviour for the first time in Nicosia, Cyprus. Cyprus is located in a tectonically complex area in the Eastern Mediterranean where three plates meet. The study area was chosen to cover the areas to be opened for new development. Nicosia, the capital of Cyprus, is also the island's most important cultural, industrial, commercial, and transportation centre. The study creates base maps for the soil to assess earthquake resistance crucial for construction. Microtremor Method was applied at 100 stations and the Multi-Channel Analysis of Surface Waves (MASW) method was used at 52 stations. Also, RefractionMicrotremor (Re-Mi) and L-Shaped Spatial Autocorrelation (L-SPAC) methods were carried out at 17 stations to substantiate the research. The results of the microtremor method indicate that the predominant soil period values have an average of 1 second and pre-dominant peak period values are generally found between 0.1 to $5 \mathrm{~s}$ at the study area. Peak amplitude values are observed between 1 and 2.4. The Vulnerability Index Parameter $\left(K_{g}\right)$ exceeded 20 at the central and the southern stations, and $K_{g}$ values change between 7 and 54 units. The $K_{g}$ values were found to be higher than 20 in soils where shear wave velocity is lower than $760 \mathrm{~m} / \mathrm{s}$. At the same time, the values of the predominant peak period were greater than 1 second. Cyprus is located in the Alpine Himalayan earthquake zone. The Cyprus Arc is known as the main seismic source of the island, It constitutes the tectonic border among African and Eurasian lithospheric plates in the region. During an earthquake in Nicosia, seismic waves will be amplified by an average of 1.5 times and soil deformation will occur due to the exceeding elastic limits. The results provided important insight into soil behaviour and indicated its reactions in a potential earthquake.

Keywords: microtremor, Re-Mi, L-Spac, MASW, local site effects 


\section{Introduction}

The common behaviour that soil presents during a massive earthquake, depends on the soil layers and their properties. It is known that earthquakes have an impact on the soil surface. Gmax value which controls the dynamic behaviour of the soil shows sudden changes even in very small scales in the horizontal and the vertical directions. These changes are defined by seismic $\mathrm{S}$ wave velocity values to be obtained on a small scale (Ansal et al., 2015). Therefore, when constructing earthquake-resistant engineering structures, soil properties should be investigated in detail. In these studies, soil bedrock models are prepared in one (1D) and two (2D) dimensions by using in situ methods (Nortey et al., 2018). Nowadays, MASW, Seismic Refraction, Up Hole, Down Hole, Cross Hole Seismic Studies, Single Station Microtremor, Refraction Microtremor and Array Microtremor methods are widely used as in situ methods for geophysical site investigations (Olona-Allué et al., 2008; Margaryan and Yokoi, 2008; Yalçınkaya, 2010; Claprood et al., 2011; Akgün et al., 2013a; Akgün et al., 2013b; Özdağ et al., 2015; Mohamed et al., 2016; Pamuk et al., 2017). Nicosia, which constitutes the study area, is a second-degree risky earthquake zone throughout the island of Cyprus. Nicosia region has suffered great damages as a result of historical earthquakes. Nicosia and its surroundings have different geological units that present variety on a greater scale. For this reason, this research aimed to thoroughly investigate the earthquake soil common behaviour parameters for the Nicosia district. Clay minerals were found to be abundant into the formation of soils, in the study area. As a result of clay minerals, alteration and the swelling behaviour due to the change of the water level content has been demonstrated by the studies that these soils show very sudden changes in the horizontal and vertical directions (Petrides et al., 2004; Atalar and Das, 2009). Previous studies such as United Nations Development Programme (UNDP) project between 2000 to 2004 represent valuable information from borehole data and reveals that the marl gives, in general, a shear velocity in the range of $350-825 \mathrm{~m} / \mathrm{s}$ (DeCoster et al., 2004). Vs values of Nicosia marl were calculated with a mean of $403 \mathrm{~m} / \mathrm{s}$. Mia Milea (Haspolat) village located in the northeast of Nicosia was a site of rather interesting shear-wave seismic records, resulting presumably from a high water table prevailing in that area (Eleftheriou et al., 2004). As a result of drilling works in Northern Cyprus; at a depth of 10-20 m, a low permeability marl (Hard Clay) layer is encountered. In most of the previous studies, it was observed that the groundwater level was close to the surface above this layer. The shrinkage and compressibility of marine deposited clays may effect liquefaction in the presence of groundwater in the marl layer (Ekinci et al., 2019).

Cyprus is located in the Alpine Himalayan earthquake zone, where approximately $15 \%$ of world earthquakes occur. The Cyprus Arc, which is thought to cause earthquakes in Cyprus, constitutes the tectonic border among African and Eurasian lithospheric plates in the region where the island is located. This arc is located offshore to the south of Cyprus and the majority of earthquakes are known 
to occur on this arc. Tectonic movements also occur along this arc and this indicates the cause of these earthquakes (Woodside, 1977; Jackson and McKenzie, 1988; Geiss, 1992; Robertson, 1994; Robertson, 2000; Harrison et al., 2004; Welford et al., 2015). According to historical earthquake information for the period between $26 \mathrm{BC}$ and $1900 \mathrm{AD}$, there were 8 destructive earthquakes with an intensity of 8 according to the Mercalli Intensity Scale (Ambraseys, 1965).

More than 400 earthquakes with greater intensity of 5 according to the Mercalli Intensity Scale have occurred around Cyprus in the last century and these earthquakes were felt in neighboring countries as well as in certain regions of the island (Ambraseys, 1992; Ambraseys and Adams, 1993; Algermissen and Rogers, 2004). Moreover, 14 of these earthquakes caused damage and loss of life. The most destructive earthquakes were recorded in 1918, 1941, 1953, 1995, 1996, and 1999 (Ambraseys and Adams, 1993; Papadimitriou and Karakostas, 2006). Evaluations performed on earthquakes that have occurred in historical and contemporary periods indicate that the occurrence of earthquakes and their distribution over time are not regular. Frequent recurrent earthquakes are followed by periods of seismic activity. The most active region of Cyprus in terms of earthquakes is the coastline of Paphos-Limassol-Larnaca-Famagusta covering the southern part of Cyprus (Ambraseys, 1965; Galanopoulos and Delibasis, 1965; Papazachos, 1973; Ambraseys, 1992; Ambraseys and Adams, 1993; Papazachos and Papaioannou, 1999; Papadimitriou and Karakostas, 2006; Çağnan and Tanircan, 2009; Palamakumbura and Robertson, 2016).

In the study area of Nicosia, the soil properties are likely to change even on small scales as many streams are under the influence of common accumulation. These changes were found to be effective at a depth between 10-15 meters in the vertical direction at the sides of the stream beds. Due to these reasons, it was aimed to investigate the ambient parameters such as Vs velocity, dominant period, amplification, and vulnerability index via in situ methods.

To define the general soil characteristics of the study area, the first stage of the single-station microtremor measurements were carried out at 100 points. Quasi Transfer Spectra (QTS(f)) was calculated for each measurement point. Peak period, peak amplitude, and vulnerability index contour maps were prepared from these spectra.

In the second stage, the changes in peak period maps were examined and Multi-Channel Analysis of Surface Waves Method (MASW) was applied at 52 points. As a result of MASW studies, 1D and 2D Vs velocity depth profiles and $V_{s 30}$ map were obtained on-site and soil classification maps were prepared according to National Earthquake Hazards Reduction Programme (NEHRP) regulations (BSSC, 2004). In the last stage, Refraction-Microtremor (Re-Mi) and L-Shaped Spatial Autocorrelation (L-SPAC) methods were carried out to increase the depth of the research in 17 selected points depending on the changes in $V_{s 30}$ velocity change maps. With the common evaluation of all study results, $K_{g}$ Vulnerability Index coefficients for predicting the soil deformation changes that may occur in the earthquake effect were transferred to the map environment. 


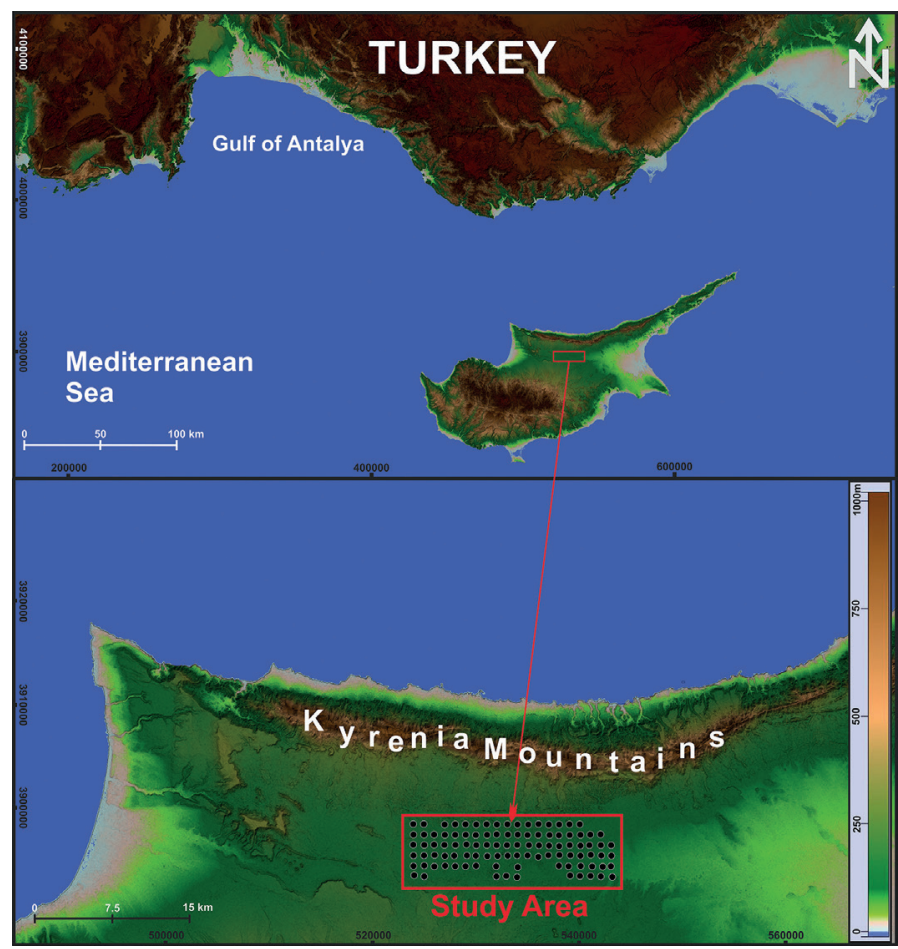

Figure 1. Location map of the study area.

Finally, the interpretation for the study area was made based on the shear velocity values $\left(V_{s} \geq 760 \mathrm{~m} / \mathrm{s}\right)$ of the Engineering Bedrock. According to the conservation of energy, changes occur on the earthquake movement resulting in amplitude-frequency spectrum up to the engineering bedrock-soil interface in an elastic behaviour (Yalçınkaya, 2004; Kanli et al., 2006; Nath, 2007; Akgün et al., 2013a; Özdağ et al., 2015).

The study area was selected in the northern part of Nicosia. All measure-ments were made on 6 lines formed in this region. Geophysical applications conducted on these lines are Microtremor measurements on 100 different stations at $1 \mathrm{~km}$ intervals and MASW Method applications on 52 different stations with $2 \mathrm{~km}$ intervals from Gonyeli at west towards to Haspolat at east and from Dikmen at North towards to Nicosia downtown the south (Fig. 1).

\section{Geology of the study area}

The selected geological zones for Cyprus is suggested by the Geological Survey Department of Cyprus's four geological zones are simply; Kyrenia, Troodos, Mamonia, and Circum Troodos Sedimentary Succession (GSD, 2002). Another 


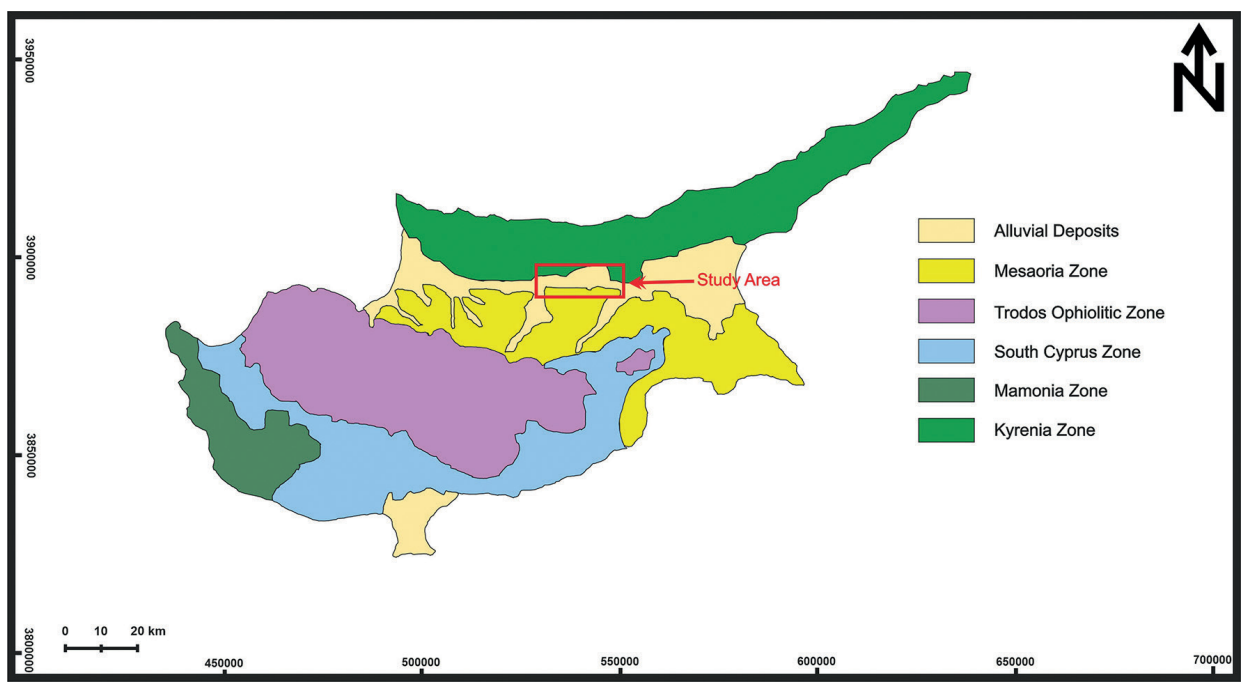

Figure 2. Geology map of the study area (modified from Atalar, (2006)).

suggestion of Cyprus geological zones is centred around six areas according to geological evolution and emplacement of its geological units: These are; Kyrenia, Mamonia (Mamonia Complex), South Cyprus, Troodos (Troodos Ophiolite), and Mesaoria zones, and the Alluviums (Fig. 2) (Atalar, 2005, 2006). In the greater Nicosia area, the eldest unit is the Troodos Ophiolite zone which contains mostly pillow lavas and plutonic rocks. The following litho-stratigraphic unit is the Kythrea Formation of sandstone, siltstone, and claystone which is equivalent to the Pakhna Formation of south Cyprus. In the upper sequences, Kalavasos (Mermertepe) formation contains gypsum, and Nicosia formation mainly contains marls. Lastly, the Athalassa formation which is equivalent to the Gürpinar formation in the north, mainly with calcarenite and sandstones, underlying the alluviums at the surface.

\section{Applications}

There are four different methods applied for the study area to estimate local site effects in Nicosia. The most important objective here is to obtain the $\mathrm{S}$ wave velocity depending on the depth. The results of the dispersion curve to be obtained from here provide variations in layer thickness and $\mathrm{S}$ wave velocity (Roberts and Asten, 2004). The methods and their applications are clarified and data analysis of these methods is explained.

\subsection{Microtremor measurements}

Microtremor measurements were performed by minimizing artificial and natural noise where strong weather conditions (wind and rain etc.) were absent. 
Additionally, measurements were made at less than 250 meters from the stations determined on the map. These measurements were generally carried out in soft soil or rock environments and the Microtremor device was covered with a bucket during the measurements.

Microtremor measurements were performed at 100 stations. Measure-ments are usually taken between 21:00-04:00 to minimize the traffic noise. A Guralp CMG 6TD 3-component velocity meter was used. Data were recorded for 20-30 minutes and $100 \mathrm{~Hz}$ sampling intervals were used. During the recording process, the data quality was continuously observed via computer, while the noise content was taken into consideration and the recording time was extended (45-60 $\mathrm{min}$ ) where the noise was high. Geopsy (SESAME, 2004) software was used in Microtremor data evaluation studies. In the data processing stage, the effect of the linear component was removed. Bandpass filtering was applied in the range of 0.05-20 Hz. scale and spectrum data separated 81.92 seconds wide windows. Windows were selected and 5\% cosine trimming was applied. For each window, the Fast Fourier Transform (FFT) was applied to obtain the amplitude spectra of each component.

Teves-Costa approach can provide preliminary information about the thickness of the soil (Teves-Costa et al., 1996). For this consideration, the predominant period has been known as:

$$
\begin{gathered}
T_{0}=\frac{4 H}{V_{s}}, \\
\frac{H}{V}=\frac{\sqrt{N S^{2}+E W^{2}}}{Z},
\end{gathered}
$$

In Eq. (1), $H$ represents the soil layer thickness and $V_{s}$ is known as shear wave velocity in this equation. In Eq. (2), $H / V$ is the horizontal over vertical spectrum ratio, $N S$ is the N-S component's amplitude spectrum, $E W$ is the E-W Component's amplitude spectrum, and $Z$ is the vertical component's amplitude spectrum.

The $H / V$ technique originally proposed by Nogoshi and Igarashi (1971), and became wide-spread by Nakamura (1989), consists of estimating the ratio between the Fourier amplitude spectra of the horizontal $(H)$ to vertical $(Z)$ components of the ambient noise vibrations recorded at one single station.

$$
K_{g}=\frac{A_{0}^{2}}{F_{0}}
$$

Nakamura (1997) examined the relationship between the structural damage and the $K_{g}$ (vulnerability index) value after an earthquake and determined that the damage rate increased in areas where the $K_{g}$ value was greater than 20 units. $K_{g}$ is explained in Eq. (3). $\mathrm{A}_{0}$ is the maximum amplitude of $H / V$ spectra and $F_{0}$ is the frequency corresponding to $A_{0}$ (also called predominant soil vibration frequency). The process of the QTS follows 6 main steps. These are first a three-component data record; second; selection of time windows (avoid noise); third, estimation of Fourier amplitude spectra for each time windows; fourth, calculating 


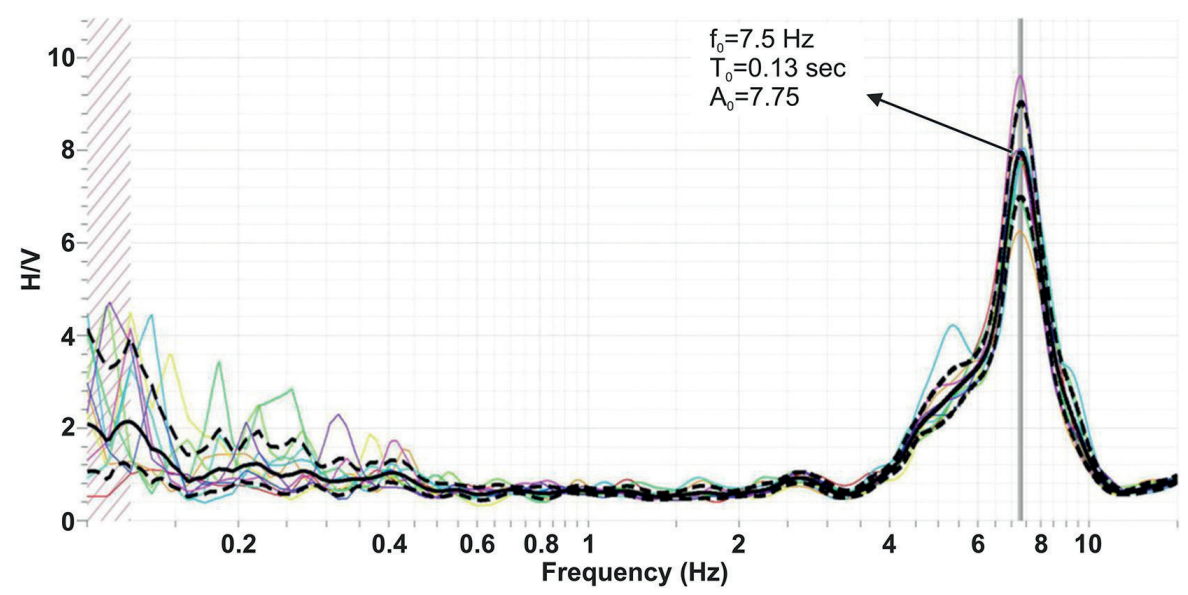

Figure 3. An example of the interpretation of the $H / V$ spectral ratio.

quadratic mean value of two horizontal components; the fifth; obtaining the $H / V$ ratio for each window and last sixth; obtaining the QTS.

The interpretation of the $H / V$ spectral ratio is intimately related to the composition of the seismic wavefield responsible for the ambient vibrations, which in turn is dependent both on the sources of these vibrations and on the underground structure. It is also related to the effects of the different kinds of seismic waves on the $H / V$ ratio $\mathrm{QTS}(f)$ spectrum which provides $H / V$ ratios for each window represents E3 station microtremor recording and calculated predominant amplitude value $A_{0}=7.75$ a predominant frequency $f_{0}=7.5 \mathrm{~Hz}$ or predominant soil period value $T_{0}=0.13 \mathrm{sec}$ (Fig. 3).

The $H / V$ spectral ratio method is an experimental technique to evaluate some characteristics of soft-sedimentary (the soil) deposits. This technique is the most effective in estimating the natural frequency of soft soil sites when there is a large impedance contrast with the underlying bedrock. The method is especially recommended in areas of low and moderate seismicity, due to the lack of significant earthquake recordings, as compared to high seismicity areas (SESAME, 2004).

The concept of the soil transfer function is used to define the earthquake force that creates dynamic load in the lateral direction in soils. The soil transfer function can be obtained theoretically or practically. Practically Nakamura (1989) method is described in this study. Finally, depending on the stress-strain relationship, soil deformation is defined (elastic, elastoplastic, and plastic).

The soil transfer function can be calculated separately in three different ways by the common usage of $\mathrm{S}$ wave velocity, $\mathrm{P}$ wave velocity, and commonly used theoretically (Özdağ et al., 2015). Theoretical soil transfer functions are calcu- 
lated by using the viscoelasticity of soil layers in the frequency environment. During the calculation of the theoretical transfer spectrum process, $\mathrm{P}$ and $\mathrm{S}$ velocity values, thicknesses, densities, and damping factors to be included in the bedrock within situ studies are used as input parameters. Using these assumptions, an observational soil transfer function is obtained. The soil transfer function gives information about how the earthquake waves passing from the bedrock to the soil is changed (Akgün et al., 2013a).

Quasi Transfer Spectra (QTS) which consists of the seismic impedance differences between the layers and define the effects of the seismic wave at the amplification and frequency is obtained by using the microtremor method data (Dindar et al., 2015).

Seismic waves spend a significant part of their travel from the source to the earth in the hard bedrock that forms the earth's crust. The last stage of their travel takes place in the so-called loosely bonded surface layers, whose properties differ greatly from the bedrock, and the physical properties of these ground layers largely determine the characteristics of the vibration observed on the earth (Yalçınkaya, 2010).

In this context, it is assumed that the $\mathrm{S}$ wave velocity is less than $760 \mathrm{~m} / \mathrm{s}$ in the surface layer called soil, and the places where the $\mathrm{S}$ wave velocity is greater than $760 \mathrm{~m} / \mathrm{s}$ are called engineering bedrock, and the places where the $\mathrm{S}$ wave velocity is greater than $3,000 \mathrm{~m} / \mathrm{s}$ are called seismic bedrock (Nath, 2007).

In the so-called seismic bedrock, it is assumed that there are no physical changes in the lateral direction from the depth level of the layer in question and that there is a more homogeneous structure compared to the upper depth levels and the $\mathbf{S}$ wave velocity is greater than $3,000 \mathrm{~m} / \mathrm{s}$ in this layer.

\subsection{Multichannel analysis of surface waves measurements}

The method aims to reveal the $\mathrm{S}$ wave velocity structure in $1 \mathrm{D}$ and $2 \mathrm{D}$ towards to the required depth (Apostolidis et al., 2004; Roberts and Asten, 2004). Multichannel Analysis of Surface Waves (MASW) is a method in which various artificial sources (sledgehammer, weight drop, etc.) are used. $V_{s 30}$ is widely used in velocity calculations, particularly because it is not affected by low-velocity zones (Park et al., 1999). MASW method measurements were performed in 52 stations in the field studies. MASW method applications were administered with average intervals of 2 kilometers and measurements performed using a sledgehammer with a profile length of $120 \mathrm{~m}$ and offsets were selected on 5, 10 and $15 \mathrm{~m}$ shot range. Hard flat media is used to avoid repeated reflection at selected stations when shooting. Additionally, care was taken to work at intervals without traffic noise while shooting. Measurements were performed on asphalt, flat, or rock environments with flat inclined surfaces. In the study area, a total of 6 linear lines were formed, $19 \mathrm{~km}$ long in the west-east direction, and $5 \mathrm{~km}$ wide in the north-south direction, covering a total area of $95 \mathrm{~km}^{2}$ area. DOREMI device was used with 24 receivers (featured as $4.5 \mathrm{~Hz}$; frequency and vertical $\mathrm{P}$ geo- 
phones). The geophones were located between 2-5 meters intervals. Recording length has been set with 2 seconds $(2,000 \mathrm{~ms})$ and the sampling interval has been set as 0.125 milliseconds.

The first step of data processing in most surface-wave methods is estimating one or more dispersion curves which are called dispersion analysis. Generally, it has been the fundamental-mode (M0) curve usually estimated. Theoretical M0 curves are then calculated for different earth models by using a forward modeling design. Then, after the inversion of the initial model with the calculated model, $V_{s}$ values, the final model for each depth values were calculated for each station. $V_{s 30}$ values were plotted on the map and the soil classification was made according to the NEHRP directive (Fig. 7).

\subsection{Re-Mi and L-SPAC measurements}

These passive source methods are preferred for deeper analysis of soil than active source methods. In Refraction Microtremor (Re-Mi) method, data collection is performed by using a linear array. The method reveals the $\mathrm{S}$ wave velocity structure of the soil to the required depth in one dimension (Apostolidis et al., 2004; Roberts and Asten, 2004). The Re-Mi method, which is also defined as Array Microtremor Method, was revised by Asten (2006) as the Spatially Averaged Coherency Spectra (SPAC) method. The fundamental of the SPAC method is the Rayleigh waves obtained from the natural tremor (vibration) recording of the earth. Re-Mi and L-Shaped Spatially Averaged Coherency Spectra (L-SPAC) methods were carried out with the help of the DoReMi 24-channel seismic device. The data was collected using 24 channel vertical $\mathrm{P}$ geophones applying the Re-Mi method. In Re-Mi method applications measurement recording time was 30 seconds and 30 measurements made in each station. Besides geophone intervals were $7 \mathrm{~m}$ and here, measurements had been improved with two multi-cable connections with 11 geophones. Thus, in the system with 24 receivers, five geophones were used in two-way laying from the centre. For example, geophones are generally positioned at existing channels $2,4,6,8,10,12,14,16,18,20,22$.

In the L-SPAC method, the geometry of the arrangement was adjusted to be $50 \mathrm{~m}$ on the $\mathrm{x}$-axis and $50 \mathrm{~m}$ on the $\mathrm{y}$-axis with the gauge intervals of $10 \mathrm{~m}$. Each profile was recorded for 20 to 30 seconds. In each measurement, three stacking was made. In the L-SPAC applications, the measurements were carried out by positioning two $50 \mathrm{~m}$ long pairs at an angle between 90-120 degrees. Accordingly, phase velocities with frequencies between 5 and $25 \mathrm{~Hz}$ were calculated from the MASW method survey, and values between 0 and $12 \mathrm{~Hz}$ were determined by L-SPAC and Re-Mi techniques.

\section{Results}

The evaluations of all measurements are explained with the following contour maps from Fig. 4 to Fig. 7. The QTS graphs were obtained for each station. The 


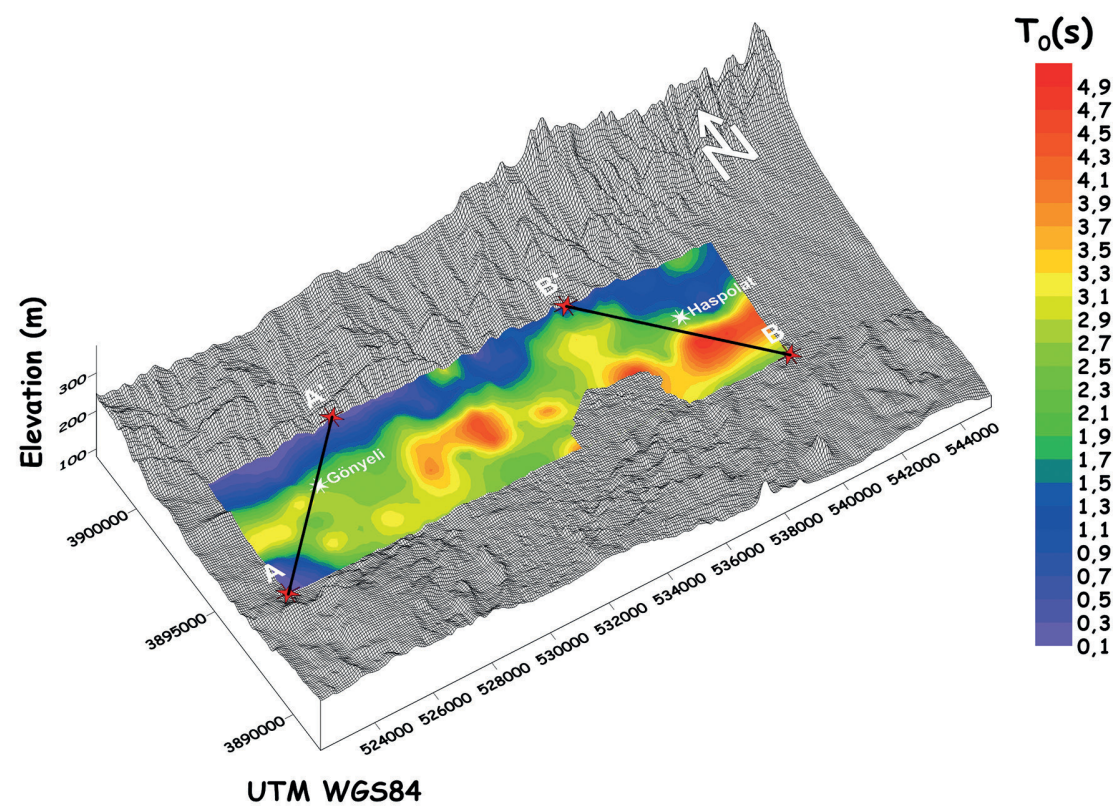

Figure 4. Peak period $\left(T_{0}\right)$ map of the study area and performed lines on the map (A-A' and B-B'). (Revised from Dindar et al., 2015; Akgün et al., 2016)

peak period $\left(T_{0}\right)$, peak amplitude $A_{0}$, and $K_{g}$ values obtained from the QTS spectra were calculated and presented separately in Figs. 4 to 7. Additionally, SW-NE directional A-A' and SE-NW directional B-B' profiles were prepared to investigate the effect of topographic changes on the profile based on $\underline{A}_{0}$ and $T_{0}$ values.

Figure 4 reveals the predominant period values with a $T_{0}$ map where the values differ between 0.1 and 4.9 seconds. Predominant soil period (peak period) values obtained from the Quasi Transfer Spectrum are usually lower than 1 second in the north of the study area. Here, the seismic impedance changes in the engineering bedrock seem to reduce at the north sides of the study area. The dominant period values are greater than 1 second in the centre of the area and this indicates that the engineering bedrock is deeper than 30 meters. In the southeast of the area, $T_{0}$ values were found to be 4 and above. This region probably consists of a very thick solid soil layer. In the field studies, the soil profiles, according to the measurement results made at 52 points by the MASW method, soil profiles were generally observed between 200 and $700 \mathrm{~m} / \mathrm{s}$. The soil profiles show a generally 3 -layer environment at a depth of 30 meters. The engineering bedrock that is nearly equal to $760 \mathrm{~m} / \mathrm{s}$ values were reached at very few points. In the north of the study area where $T_{0}$ values are lower than 1 second, the shear wave velocity values $\left(V_{s}\right)$ are calculated higher than $760 \mathrm{~m} / \mathrm{s}$. It reveals that the Kythrea formation may represent engineering bedrock in the 


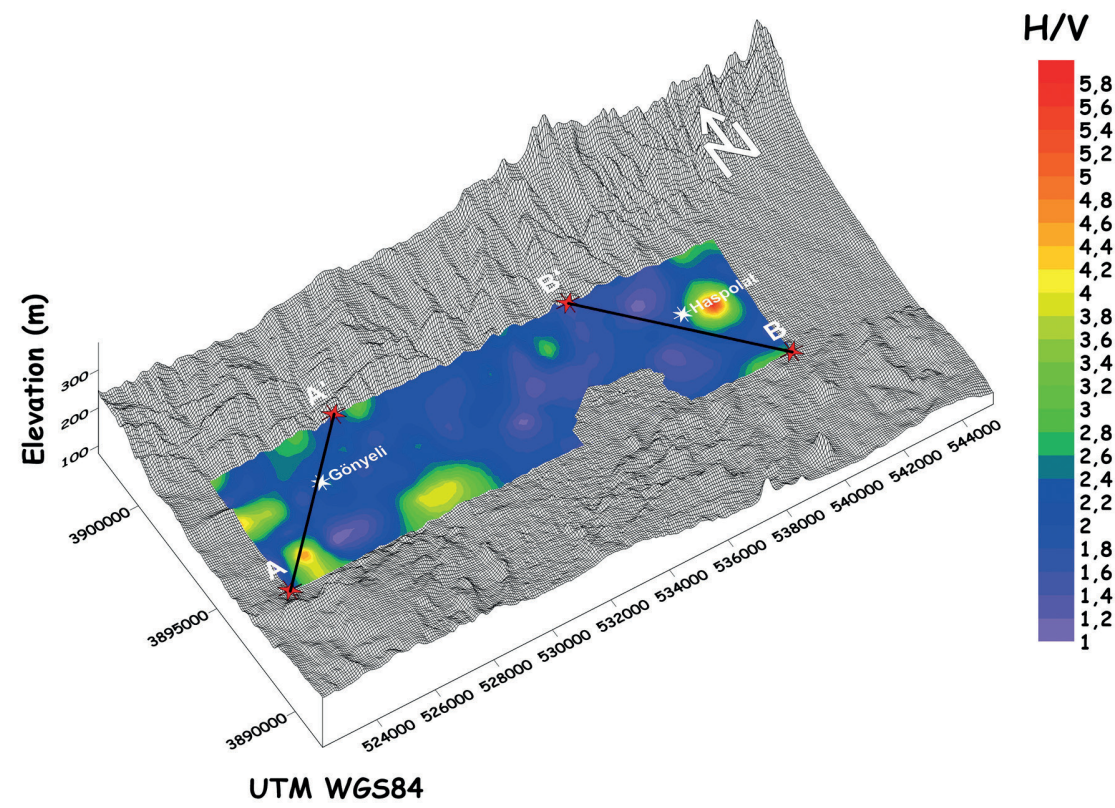

Figure 5. Peak amplitude $\left(A_{0}\right)$ map of the study area and performed lines on the map (A-A' and B-B') (Revised from Dindar et al., 2015; Akgün et al., 2016).
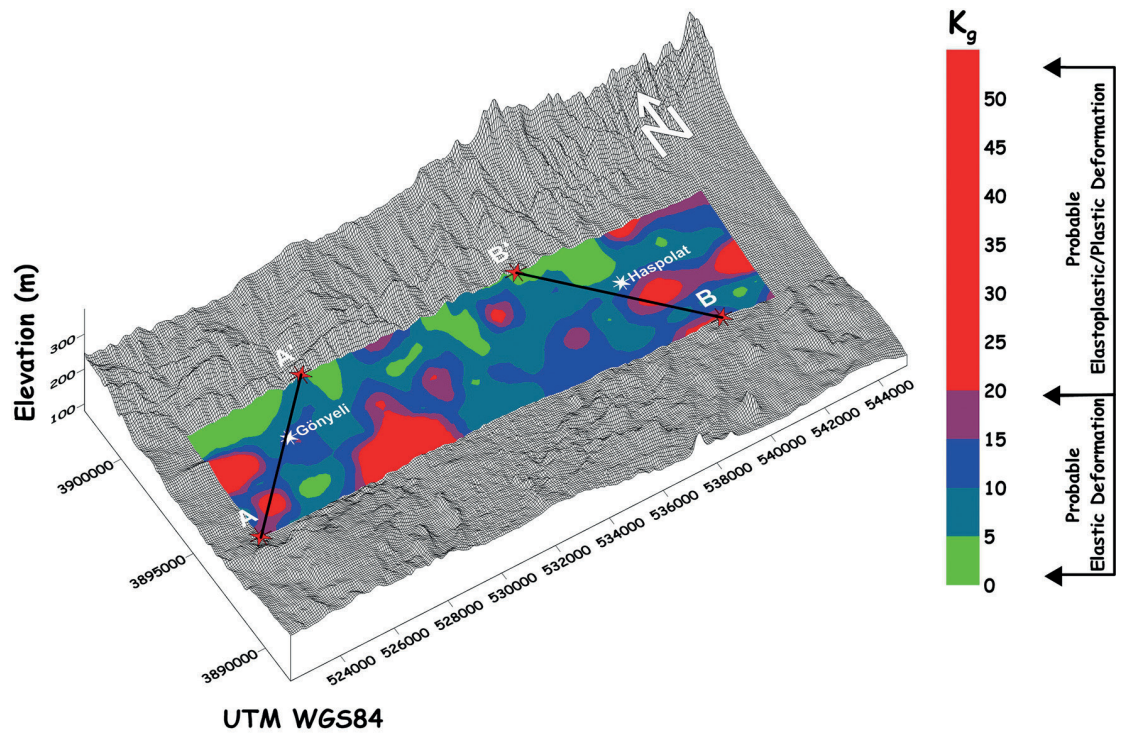

Figure 6. Vulnerability index values $\left(K_{g}\right)$ map of the study area and performed lines on the map (A-A' and B-B'). (Revised from Dindar et al., 2015; Akgün et al., 2016) 
north of the study area. However, the $V_{s}$ values calculated lower than $760 \mathrm{~m} / \mathrm{s}$, show comparable results with $A_{0}$ and $T_{0}$. Peak amplitude values show higher values than 1 unit.

Figure 5 illustrates the amplitude values according to the $A_{0}$ peak amplitude distribution map, which is obtained from the QTS calculated for the area of study. Amplitude values according to $A_{0}$ peak are observed in the values 1 to 2.4 as a dominant class. The fact that the peak amplitude values greater than 1 indicates that the effect of displacement in the spectrum of earthquake waves will increase. Based on these findings, we can say that in the event of a destructive earthquake, the seismic waves will be amplified through the ground by an average of 1.5 times.

In Fig. 6, the calculated $K_{g}$ values obtained from the quasi transfer spectra increase as they go south in the study area. In the centre of the study area, the values were between 10-20 units and some stations in the south were 20 units and above. In the study area, considering $K_{g}$ values greater than 20 units, soil deformation changes the behaviour of the soil under dynamic load that will occur due to the elastic limits.

Additionally, In Fig. 7 in the western part of the study area, group C and at the north of the study area, B and C types are observed by using MASW, Re-Mi, and L-SPAC methods. Furthermore, SW-NE-oriented A-A' line and SE-NW directional B-B' profiles are examined on the map to investigate the effect of changes on the $V_{s 30}$ values.

In Fig. 7, according to the $V_{s 30}$ map, values were obtained between 260 and $820 \mathrm{~m} / \mathrm{s}$. According to the NEHRP regulations; these values were observed to be

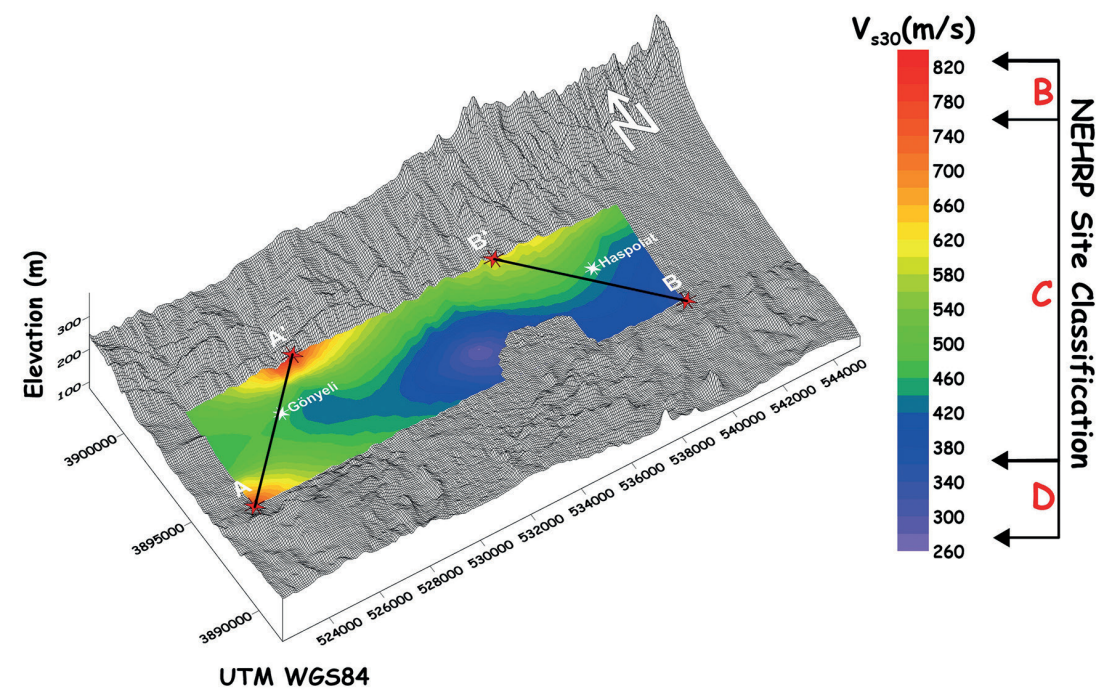

Figure 7. $V_{s 30}$ map of the study area and performed lines on the map (A-A' and B-B'). 
dominated by B, C, and D group types. In the south of the study area, soil types are $\mathrm{C}$ and $\mathrm{D}$ type.

In the north of the study area, the dominated geological formation is the Kythrea group which is highly allochthonous dolomites, limestones, and marbles. Predominant soil period (peak period) values obtained from the QTS are usually lower than 1 second in the north of the study area. Here, the seismic impedance changes in the engineering bedrock reduce at the north sides of the study area.

The dominant period values are greater than 1 second in the centre of the area and this indicates that the bedrock thickness is greater than $30 \mathrm{~m}$. In the southeast of the area, $T_{0}$ values were found to be 4 and above. This region is potentially consisting of a very thick solid soil layer.

Elevation, amplitude, predominant peak period, and $V_{s 30}$ values distribution were presented with distance in Fig. 8 according to the performed lines A-A' and B-B'. The elevation trend is constant until the first $6 \mathrm{~km}$. It is increasing towards the North direction and it reveals that the changing scale is approximately $30 \mathrm{~m}$ at 6 to $8 \mathrm{~km}$ of the line from south-west to south-east direction. On the other hand, the second line which is presented as B-B' showing an increasing line from the most SW of the study area. The values of elevation are varying between 140-180 m high.

Amplitude values vary between 1-6 units range for the first performed line which refers to A-A'. There is 2 main peak or sudden increase at the line. The first peak is at approximately $1,500 \mathrm{~m}$. Also, the second peak has a smooth maximum and it is observed at the interval of 4 to $6 \mathrm{~km}$. These two maximum points are calculated as either 3 units or 2 units according to the A-A' line. On the other hand, there is a similar trend for B-B' line. However, the first peak is at a $4 \mathrm{~km}$ distance from the most SE of the study area. The first peak is 6 units and the second one is averagely 2.5 units.

Pre-dominant peak period values generally have a scale between 0 to 5 units in the study area according to Fig. 4. The performed lines A-A' and B-B' has no similar trends in Fig. 8. Therefore SW-NE direction for A-A' it has lower values at the first and the last kilometers of the study area. Besides it has a maximum of 3 seconds at the 4,000 m of the study area from the SW to the NE. Oppositely there is a decreasing graphic from the beginning to the end of the line for B-B'.

The $V_{s 30}$ values referring to Fig. 8 shows two different kinds of lines. The first line gives a concave-up graph and the other one shows an increasing graph for the plotted area. Therefore A-A' has a minimum value which is averagely $500 \mathrm{~m} / \mathrm{s}$ at $4 \mathrm{~km}$ from the beginning of the A-A'. On the other hand the values of this line named group $\mathrm{C}$ according to NEHRP which represents very dense soil or soft rock. A-A' line represents a newly developing city area. B-B' line represents Miea Milia/Haspolat area. Generally, the data observed in a range between $500-800 \mathrm{~m} / \mathrm{s}$ for A-A' and 400-600 m/s for B-B'. 

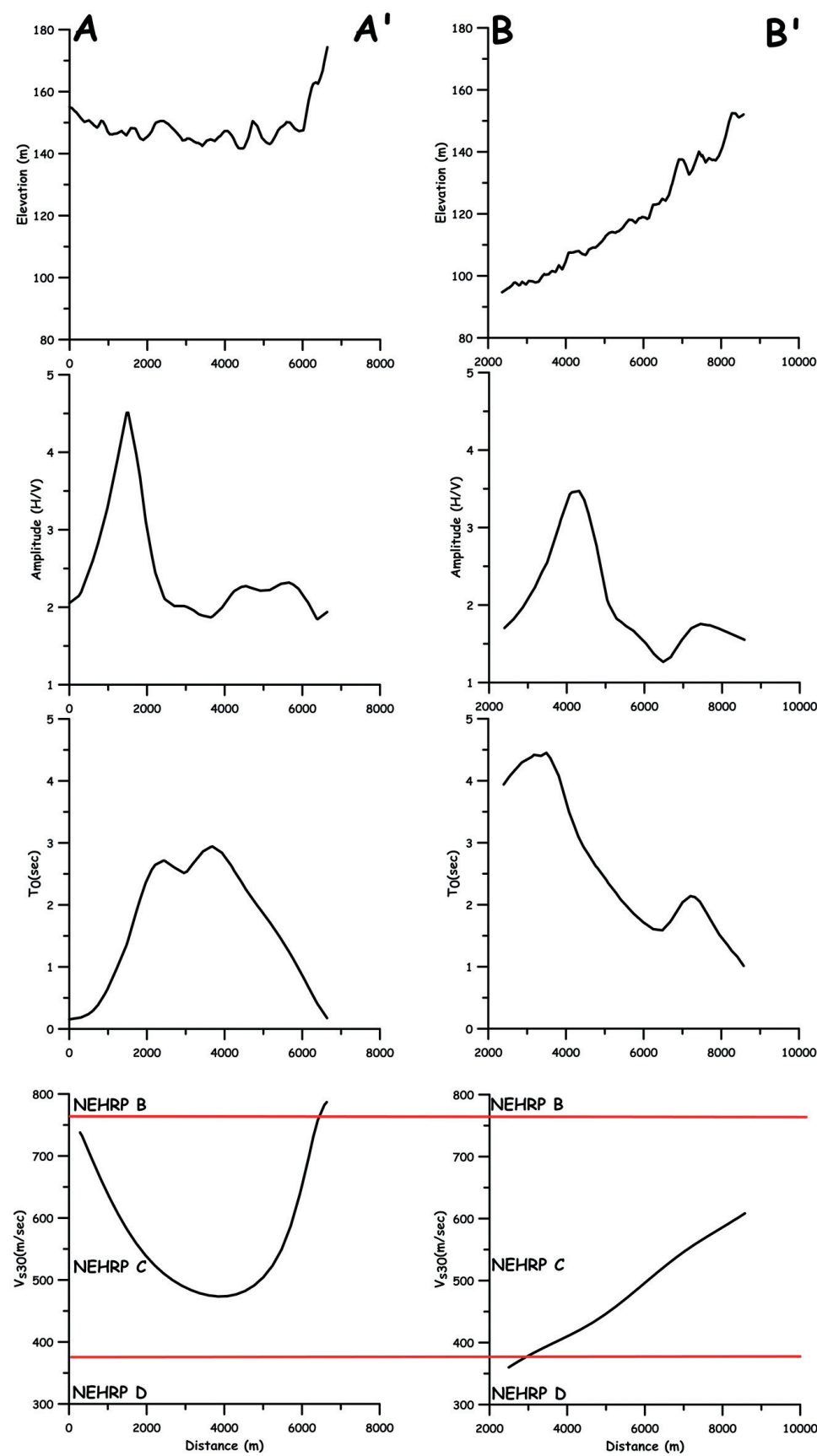

Figure 8. Elevation, amplitude, predominant peak period and $V_{s 30}$ values distribution of A-A' and B-B' Lines. 


\section{Discussion}

This research took over three years to complete and create foundations for a better understanding of soil behaviour through the use of novel combinations of multiple measurement methods.

In this study, local site effects that will control the behaviour of soils in Nicosia and its immediate surroundings under dynamic effects (earthquake motion) have been investigated and evaluated by geophysical methods.

When the QTS amplitude map (H/V) (Fig. 5) is examined, it is seen that the amplitudes vary between $1-5.8$. This means that the changes in the amplitude-frequency values of the earthquake waves that will reach the ground surface from the bedrock will increase approximately twice. This phenomenon must be taken into consideration when designing engineering structures that are likely to be built in the study area.

$\mathrm{K}_{\mathrm{g}}$ Vulnerability index values are generally average of 20 values of the study area where values close to the threshold value are observed. S-wave velocity in the same regions was found to be less than $760 \mathrm{~m} / \mathrm{s}$ for $30 \mathrm{~m}$ depth and at the same time, the values of the ground dominant vibration period were greater than $1 \mathrm{~s}$. In these areas, in the event of a possible earthquake, the lateral deformation is likely to be outside the elastic limits. The highest velocity values in the study area were obtained in the northwest of the study area (Fig. 8).

When $\mathrm{S}$ wave velocities obtained for $30 \mathrm{~m}$ depth, values of soil predo-minant period, and $K_{g}$ vulnerability index parameter was examined compara-tively; In areas where $\mathrm{S}$ velocity is increased, $K_{g}$ vulnerability index values decreased. The reason for this decrease is that the lateral deformation of the soil under a dynamic load is directly related to the $\mathrm{S}$ wave velocity. At the same time, it has been observed that the soil predominant period increases in these regions, ie the bedrock depth increases. According to these definitions, the depth of bedrock of most of the study area is more than $40 \mathrm{~m}$. When this is taken into consideration, it is recommended to create elastic design spectra in situ for the structures planned to be constructed within the study area.

In the south of the study area and settlement Haspolat, the soil thickness over $30 \mathrm{~m}$, and the average period values of 2-2.5 seconds were calculated (Fig 4.). These values are consistent with the soil classifications specified in Earthquake regulations and other classifications based on $V_{s 30}$.

The higher values of 1 unit point out a layered medium in shallow scale in peak amplitude map. These values checked with $V_{s}$ values and it shows soil effect will magnify the potential earthquake wave and this means that the definition of the engineering bedrock for the first $30 \mathrm{~m}$ for Nicosia soils are not sufficient.

The $V_{s 30}$ designation can be used in areas with such a soil thickness. According to the results of this researches, it is recommended to make special design spectra according to the average $V_{s}$ velocity values obtained for the study area where tall buildings are located. 


\section{Conclusions}

In this study, geophysical methods were used to obtain QTS, $T_{0}, A_{0}, K_{g}$, and $V_{s 30}$ values with NEHRP soil classification. For the NEHRP classification, $V_{s 30}$ velocity values were calculated from MASW Method applications at 52 stations. For the peak period, peak amplitude, and vulnerability values, single-station broadband Microtremor measurements were performed at 100 stations. $V_{s 30}$ values across the study area vary from 260 to $820 \mathrm{~m} / \mathrm{s}$. According to NEHRP soil classifications, B, C, and D soil groups which determines rock, very dense soil/ soft rock, and stiff soil are dominant in the study area. According to these findings, there is a rocky medium in the northernmost part of the region, very dense soil or soft rock in the centre, and solidified soil groups in the south and southeast. Peak period values range from 0.1 seconds to 5 seconds. The dominant period values obtained from the Quasi Transfer Spectrum (QTS) are usually $T_{0}<1$ second in the north of the field. Here, the seismic impedance changes in the engineering bedrock are reduced. The dominant period values obtained in the range of $T_{0}>1$ in the centre of the area which indicate that the engineering bedrock at the centre is deeper than $30 \mathrm{~m} . K_{\mathrm{g}}$ values change between $7-54$ units. Where the $K_{g}$ changes are greater than 20, soil deformation changes for the behaviour of the soil under dynamic load will occur due to the elastic limits. As a result of this analysis, the findings obtained regarding the behaviour of soil-structure common interaction demonstrate the overall effects that will occur during a destructive earthquake.

Acknowledgments - This study constitutes a part of Hilmi Dindar's Ph.D. thesis at the Institute of Natural and Applied Sciences of Dokuz Eylül University, Izmir, Turkey. This study is supported by Near East University Scientific Research Projects Coordination Unit Project No: FEN 2016-2-005. The authors are grateful for financial support. The preliminary results of the study are presented in $4^{\text {th }}$ International Conference on New Developments in Soil Mechanics and Geotechinal Engineering (TRNC) and VI International Scientific Conference of Young Scientists and Students (Baku, Azerbaijan).

\section{References}

Akgün, M., Gönenç, T., Pamukçu, O., Özyalın, Ş. and Özdă̆, Ö. C. (2013a): Integrated geophysical methods for the determination of engineering bedrock: İmir New City Centre, Turkish J. Geophys., 18, 67-80 (in Turkish).

Akgün, M., Gönenç, T., Tunçel, A. and Pamukçu, O. (2013b): A multi-approach geophysical estimation of soil dynamic properties in settlements: A case study in Güzelbahce-İzmir (Western Anatolia), J. Geophys. Eng., 10, 045001, https://doi.org/10.1088/1742-2132/10/4/045001.

Akgün, M., Dindar, H., Atalar, C. and Özdağ, Ö. C. (2016): Site characterization for earthquake resistant building design: Case study of TRNC Nicosia, 4th International Conference on New Developments in Soil Mechanics and Geotechinal Engineering, 2-4 June 2016, Near East University, Nicosia, North Cyprus. 
Algermissen, T. and Rogers, A. (2004): Simulation of earthquake risks (losses) in Nicosia, in Seismic hazard and risk assessment of Greater Nicosia area, edited by DeCoster M., Zomeni Z., Panayides I., Petrides G. and Berksoy O. UNOPS Report, Nicosia, Cyprus, VII, 1-32.

Ambraseys, N. N. (1965): The seismic history of Cyprus, Rev. Union Int. Secours, Geneva, 3, 25-48.

Ambraseys, N. N. (1992): Reappraisal of the seismic actvity in Cyprus: 1894-1991, B. Geofis. Teor. Appl, 34 (N. 133), 41- 80.

Ambraseys, N. N. and Adams, R. D. (1993): Seismicity of the Cyprus region, Terra Nova, 5, 85-94, https://doi.org/10.1111/j.1365-3121.1993.tb00229.x.

Ansal, A., Tönük, G. and Kurtuluş, A. (2015): A methodology for site specific design earthquake, in: Earthquake Risk and Engineering towards a Resilient World, SECED 2015 Conference, 9-10 July 2015, Cambridge, UK, 8 pp, last available at: https://www.seced.org.uk/images/newsletters/ ANSAL,\%20TONUK,\%20KURTULUS.pdf

Asten, M. W. (2006): On bias and noise in passive seismic data from finite circular array data processed using SPAC methods, Geophysics, 71(6), V153-V162, https://doi.org/10.1190/1.2345054.

Atalar, C. (2005): The origin and characteristics of Cyprus clays, Extended Abstract Book of $57^{\text {th }}$ Geological Congress of Turkey, Ankara, Turkey, 144-148.

Atalar, C. (2006): Engineering properties and problems of Cyprus soils, in: Proceedings of the Symposium on Recent Applications in Engineering Geology, 25-27 May 2006, Denizli, Turkey, 629-638 (in Turkish).

Atalar, C. and Das, B. M. (2009): Geotechnical properties of Nicosia soils, Cyprus. International Conference on New Developments in Soil Mechanics and Geotechnical Engineering, 2, 28-30.

Building Seismic Safety Council, BSSC (2004): NEHRP recommended provisions for seismic regulations for new buildings and other structures, Federal Emergency Management Agency, Washington, D.C.

Çağnan, Z. and Tanırcan, G. B. (2009): Seismic hazard assessment for Cyprus, J. Seismol., 14, 225-246, https://doi.org/10.1007/s10950-009-9163-1.

Claprood, M., Asten, M. W. and Kristek, J. (2011): Using the SPAC microtremor method to identify 2D effects and evaluate 1D shear-wave velocity profile in Valleys, B. Seismol. Soc. Am., 101, 826-847, https://doi.org/10.1785/0120090232.

DeCoster, M., Zomeni, Z., Panayides, I., Petrides, G. and Berksoy, O. (Eds.) (2004): Seismic hazard and risk assessment of the greater Nicosia area. UNOPS Report, Nicosia, Cyprus.

Dindar, H., Tunçel, A. , Özdağ, Ö. C., Akgün, M., Atalar, C., İpek, Y. and Özyankı, A. (2015): Estimation of the site-bedrock model by using microtremor method: A case study in Lefkoşa - T.R.N.C., Multidisciplinary Approach To Solving Problems Of Geology And Geophysics - VI International Scientific Conference of Young Scientists and Students (ICYSS-2015), 12-15 October 2015, Baku, Azerbaijan, 10-11.

Dindar, H., Dimililer, K., Özdağ, Ö. C., Atalar, C., Akgün, M. and Özyankı, A. (2017): Vulnerability index assessment using neural networks (Viann): A case study of Nicosia, Cyprus, SPRS Annals of Photogrammetry, Remote Sensing \& Spatial Information Sciences, IV, 14-15.

Ekinci, A., Ince, C. and Ferreira, P. M. V. (2019): An experimental study on compression and shrinkage behaviour of cement-treated marine deposited clays, Int. J. Geosynth. Ground Eng., 5, 21, https://doi.org/10.1007/s40891-019-0172-z.

Eleftheriou, S. Schindler, J. Christophi, C. Tsiolakis, E. and Efthymiou, M. (2004): Lithologic model and shear wave parameters, in: Seismic hazard and risk assessment of Greater Nicosia area, edited by DeCoster M., Zomeni Z., Panayides I., Petrides G. and Berksoy O. UNOPS Report, Nicosia, Cyprus, IV, 1-53.

Galanopoulos, A. and Delibasis, N. (1965): The seismic activity in the Cyprus area, Prakt. Akad. Athenon, 40, 387-405.

Geiss, E. (1992): Is there plate tectonics in the Mediterranean area? in: The Geology of Libya, edited by Salem, M. J., 6, 2407-2413.

Geological Survey Department (2002): Geology of Cyprus. Edited by Petrides, G., Nicosia, Cyprus. 
Harrison, R. W., Newell, W. L., Batıhanl, H., Panayides, I., McGeehin, J. P., Mahan, S., Őzhür, A., Tsiolakis, E. and Necdet, M. (2004): Tectonic framework and Late Cenozoic tectonic history of the northern part of Cyprus: Implications for earthquake hazards and regional tectonics, J. Asian Earth Sci., 191-210, https://doi.org/10.1016/S1367-9120(03)00095-6.

Jackson, J. and McKenzie, D. (1988): The relationship between plate motion and seismic moment tensors, and the rate of active deformation in the Mediterranean and Middle East, Geophys. J., 93, 45-73, https://doi.org/10.1111/j.1365-246X.1988.tb01387.x.

Margaryan, S. and Yokoi, T. (2008): On the stability of spac and linear array methods. 14th World Conference on Earthquake Engineering, China Earthquake Association, 1-24

Mohamed, E. K., Shokry, M. M. F., Hassoup, A. and Helal, A. M. A. (2016): Evaluation of local site effect in the western side of the Suez Canal area by applying H/V and MASW techniques, J. African Earth Sci., 123, 403-419, https://doi.org/10.1016/j.jafrearsci.2016.07.004.

Nakamura, Y. (1989): A method for dynamic characteristics estimation of subsurface using microtremor on the ground surface, Railway Technical Research Institute, Quarterly Reports, 30(1), $25-33$.

Nakamura, Y. (1997): Seismic vulnerability indices for ground and structures using microtremor, in: World Congress on Railway Research in Florence, Italy, 1-7.

Nakamura, Y. (2009): Basic structure of QTS (HVSR) and examples of applications, in: Increasing seismic safety by combining engineering technologies and seismological data, Springer, Dordrecht, $33-51$.

Nath, S. K. (2007): Seismic microzonation framework - Principles and applications, in: Proceedings of Workshop on Microzonation, Indian Institute of Science, Bangalore, 9-35.

Nogoshi, M. and Igarashi, T. (1971): On the amplitude characteristics of ambient noise (Part 2), J. Seismol. Soc. Jpn., 24, 26-40, https://doi.org/10.4294/zisin1948.24.1_26.

Nortey, G., Armah, T. K. and Amponsah, P. (2018): $\mathrm{V}_{\mathrm{s} 30}$ mapping at selected sites within the Greater Accra Metropolitan Area, J. African Earth Sci., 142, 158-169, https://doi.org/10.1016/j. jafrearsci.2018.02.020.

Olona-Allué, J., Pulgar, J. A., Fernández-Viejo, G. and González-Cortina, J. M. (2008): Geotechnical site characterization of a flood plain by refraction microtremor and seismic refraction methods. Symposium on the Application of Geophysics to Engineering and Environmental Problems, 437445.

Özdağ, Ö. C., Gönenç, T. and Akgün, M. (2015): Dynamic amplification factor concept of soil layers: A case study in İzmir (Western Anatolia), Arab. J. Geosci., 8, 10093-10104, https://doi.org/10.1007/ s12517-015-1881-9.

Palamakumbura, R. N. and Robertson, A. H. (2016): Pleistocene terrace deposition related to tectonically controlled surface uplift: An example of the Kyrenia Range lineament in the northern part of Cyprus, Sediment. Geol., 339, 46-67, https://doi.org/10.1016/j.sedgeo.2016.03.022.

Pamuk, E., Akgün, M., Özdağ, Ö. C. and Gönenç, T. (2017): 2D soil and engineering-seismic bedrock modeling of eastern part of Izmir inner bay, Turkey, J. Appl. Geophys., 137, 104-117, https://doi. org/10.1016/j.jappgeo.2016.12.016.

Papadimitriou, E. E. and Karakostas, V. G. (2006): Earthquake generation in Cyprus revealed by the evolving stress field, Tectonophysics, 423, 61-72, https://doi.org/10.1016/j.tecto.2006.03.014.

Papazachos, B. C. (1973): Distribution of seismic foci in the Mediterranean and surrounding area and its tectonic implication, Geophys. J. Roy. Astr. S., 33, 421-430, https://doi. org/10.1111/j.1365-246X.1973.tb02377.x.

Papazachos, B. C. and Papaioannou, C. A. (1999): Lithospheric boundaries and plate motions in the Cyprus area, Tectonophysics, 308, 193-204, https://doi.org/10.1016/S0040-1951(99)00075-X.

Park, C. B., Miller, R. D. and Xia, J. (1999): Multichannel analysis of surface waves, Geophysics, 64, 800-808, https://doi.org/10.1190/1.1444590. 
Roberts, J. C. and Asten, A. C. (2004): Resolving a velocity inversion at the geotechnical scale using the microtremor (passive seismic) survey method, Explor. Geophys., 35, 14-18, https://doi. org/10.1071/EG04014.

Robertson, A. H. F. (1994): Probing continental collision in the Mediterranean Sea, Eos, Transactions American Geophysical Union, 75, 233-239, https://doi.org/10.1029/94EO00909.

Robertson, A. H. F. (2000): Tectonic evolution of Cyprus in its Easternmost Medi-terranean setting, in: Proceedings of the Third International Conference on the Geology of the Eastern Mediterranean, edited by Panayides, I., Xenophontos, C. and Malpas, J., 11-44.

SESAME (2004): Guidelines for the implementation of the H/V spectral ratio technique on ambient vibrations: Measurements, processing and interpretation, European Research Project WP12-Deliverable D23.12, 62 pp, last available at http://sesame.geopsy.org/Papers/HV_User_Guidelines.pdf

Teves-Costa, P., Matias, L. and Bard, P. Y. (1996): Seismic behaviour estimation of thin alluvium layers using microtremor recordings, Soil Dyn. Earthq. Eng., 15, 201-209, https://doi. org/10.1016/0267-7261(95)00038-0.

Welford, J., Hall, J., Hübscher, C., Reiche, S. and Louden, K. (2015): Crustal seismic velocity structure from Eratosthenes Seamount to Hecataeus Rise across the Cyprus Arc, Eastern Mediterranean, Geophys. J. Int., 933-951, https://doi.org/2010.1093/gji/ggu447.

Woodside, J. M. (1977): Tectonic elements and crust of the Eastern Mediterranean Sea, Mar. Geophys. Res., 3, 317-354, https://doi.org/10.1007/BF00285658.

Yalcinkaya, E. (2004): Investigation of parameters affecting the soil amplification for 1-D models, Istanbul Univ. Eng. Fac. Earth Sci. Rev., 17, 47-56.

Yalçınkaya, E. (2010): Why is the soil so important, Bull. Geophys., 63, 77-80 (in Turkish).

\title{
SAŽETAK
}

\section{Procjena amplifikacijskih efekata površinskih slojeva tla i dinamičko ponašanje tla u Nikoziji na Cipru}

\author{
Hilmi Dindar, Mustafa Akgün, Cavit Atalar $i$ Özkan Cevdet Özdă̆
}

Mjerenja mikroseizmičkog nemira provedena su po prvi puta u Nikoziji na Cipru radi istraživanja ponašanja tla tijekom potresa. Cipar se nalazi u tektonski složenom području na istočnom Mediteranu gdje se susreću tri tektonske ploče. Istraživano područje odabrano je tako da uključi prostor planiran za novu gradnju. Nikozija je glavni grad Cipra, ujedno i najvažnije otočno kulturno, industrijsko, trgovačko i prometno središte. Za okrug Nikozija cilj je izračunati i objaviti osnovne karte tala da bi se procijenila potresna otpornost kako postojećih tako i novih zgrada. Mjerenja mikroseizmičkoga nemira obavljena su na 100 lokacija, a metoda višekanalne analize površinskih valova (MASW) na 52 lokacije. Također, na 17 lokacija provedene su metode refrakcijskog mikrotremora (Re-Mi) i L-Shaped Spatial Autocorrelation (L-SPAC) kako bi se povećala dubina istraživanja. Rezultati dobiveni analizom mikro-seizmičkog nemira pokazuju da su prevladavajuce vrijednosti vlastitoga perioda tla oko jedne sekunde, a prevladavajuće vrijednosti perioda s najvećom amplifikacijom uglavnom su između 0.1 i 5 s. Vrijednosti vršne amplitude uglavnom su između 1 i 2,4. Parametar indeksa povredljivosti $\left(K_{g}\right)$ prelazi 20 na središnjim i južnim lokacijama, a vrijednosti $K_{g}$ općenito variraju između 7 i 54 jedinice. Vrijednosti brzine posmičnog vala u prvih $30 \mathrm{~m}$ dubine na mjestima gdje su vrijednosti indeksa $K_{g}$ veće od 20 , manje su od $760 \mathrm{~m} / \mathrm{s}$. Istodobno su predominantni periodi bili veći od 1 sekunde. 
Cipar se nalazi u alpskom himalajskom području potresa. Ciparski luk poznat je kao glavni seizmički izvor otoka. On čini tektonsku granicu između afričkih i euroazijskih litosferskih ploča u regiji. Tijekom potresa u Nikoziji, seizmički valovi pojačat će se u prosjeku 1,5 puta i doći će do deformacije tla zbog nadmašenih granica njegove elastičnosti. Rezultati su pružili važan uvid u ponašanje tla tijekom mogućih potresa.

Ključne riječi: mikroseizmički nemir, Re-Mi, L-Spac, MASW, lokalni efekti tla

Corresponding author's address: Hilmi Dindar, Institute of Natural and Applied Sciences, Dokuz Eylül University, Buca - İmir, Turkey; tel: +90 5338629 626; e-mail: hilmi.dindar@neu.edu.tr (ORCID: 0000-0001-5348-0296).

(cc) BY-NC This work is licensed under a Creative Commons Attribution-NonCommercial 4.0 International License. 